\title{
Review Article \\ Rationale for the Successful Management of EDTA Chelation Therapy in Human Burden by Toxic Metals
}

\author{
Maria Elena Ferrero \\ Dipartimento di Scienze Biomediche per la Salute, Università degli Studi di Milano, Via Mangiagalli 31, Milan, Italy \\ Correspondence should be addressed to Maria Elena Ferrero; mariaelena.ferrero@unimi.it
}

Received 16 June 2016; Revised 31 August 2016; Accepted 18 September 2016

Academic Editor: Xudong Huang

Copyright ( 2016 Maria Elena Ferrero. This is an open access article distributed under the Creative Commons Attribution License, which permits unrestricted use, distribution, and reproduction in any medium, provided the original work is properly cited.

\begin{abstract}
Exposure to environmental and occupational toxicants is responsible for adverse effects on human health. Chelation therapy is the only procedure able to remove toxic metals from human organs and tissue, aiming to treat damage related to acute and/or chronic intoxication. The present review focuses on the most recent evidence of the successful use of the chelating agent ethylenediaminetetraacetic acid (EDTA). Assessment of toxic-metal presence in humans, as well as the rationale of EDTA therapy in cardiovascular and neurodegenerative diseases, is reported.
\end{abstract}

\section{Introduction}

The present review considers the acute and chronic treatment of toxic-metal burden with ethylenediaminetetraacetic acid (EDTA), as well as the clinical importance of other toxicmetal chelators and iron chelators.

1.1. Environmental Pollution Effects on Metal Intake. Toxic metals can provoke numerous adverse effects on human health. Individuals may be exposed to toxic metals present in the environment via multiple routes, such as the respiratory tract through inhalation of air pollution [1], or orally by ingestion of contaminated food and water [2]. Environmental exposure represents a health risk for the general population and more specifically for some professional categories.

1.1.1. High Risk Workers. Recently, a relationship between blood metals and inflammation has been seen in taxi drivers [3]. These workers showed increased whole blood concentration of mercury $(\mathrm{Hg})$, arsenic $(\mathrm{As})$, lead $(\mathrm{Pb})$, and cadmium (Cd) compared to controls; serum inflammatory markers, such as interleukin $1 \beta$, interleukin 6 , and tumor necrosis factor (TNF) $\alpha$, showed an increase. Homocysteine levels in these workers were significantly higher [hyperhomocysteinemia is a well-known risk factor for cardiovascular disease (CVD)] [4], while glutathione peroxidase (GPX) activity and renal function were impaired. These results suggest that $\mathrm{Hg}$, As, $\mathrm{Pb}$, and $\mathrm{Cd}$ can be considered important contributors to the development of CVD. In particular, the role of $\mathrm{Hg}$ toxicity in the pathogenetic mechanisms of hypertension, atherosclerosis, coronary heart disease, myocardial infarction, cardiac arrhythmias, heart-rate variability, sudden death, cerebrovascular accidents, carotid artery disease, renal dysfunction, and total mortality has already been highlighted [5]. A common mechanism of the damage provoked by toxic metals seems to be due to the induction of oxidative stress. Oxidative stress is provoked by imbalanced redox states, involving either excessive generation of reactive oxygen species (ROS) or dysfunction of the antioxidant system. For example, $\mathrm{Pb}$ and $\mathrm{Cd}$ have a high affinity for - $\mathrm{SH}$ groups in enzymes of the antioxidative defense system, such as superoxide dismutase (SOD), catalase (CAT), GPX, and glucose-6-phosphate dehydrogenase (G6PD), and subsequently inhibit their activity. Apart from targeting - $\mathrm{SH}$ groups, $\mathrm{Pb}$ and $\mathrm{Cd}$, as divalent cations, can also replace divalent bioelements that serve as important cofactors of antioxidant enzymes, such as GPX, SOD, and CAT, resulting in their inactivation. It has also been confirmed that both metals affect levels of glutathione (GSH), a tripeptide that contains more than $90 \%$ of the nontissue sulfur in the human body, representing one of the most important components of antioxidant protection. So, both $\mathrm{Pb}$ and $\mathrm{Cd}$ induce the generation of ROS and depletion of the antioxidant defense system [6]. 
Another professional category, coke-oven workers, has been examined: in these subjects, the interaction of heavy metals (As, Cd, chromium or $\mathrm{Cr}$, Nickel or $\mathrm{Ni}$, and $\mathrm{Pb}$ ) and polycyclic aromatic hydrocarbons that increases oxidative stress has been demonstrated [7]. Moreover, human exposure to $\mathrm{Pb}$ compounds has been seen to cause liver enlargement and to activate inflammatory reactions characterized by moderate cholestasis within the bile ducts; these conditions are more evident in subjects with higher $\mathrm{Pb}$ exposure levels [8].

1.1.2. Toxicity in relation to Geographic Areas. In general, man-made chemicals, including xenoestrogens, pesticides, other than heavy metals, and an unhealthy lifestyle, mainly tobacco smoking, alcohol consumption, and medical-drug abuse, are considered the major factors causing poor prenatal development through the generation of ROS and cellular oxidative damage [9]. The risks related to toxic-metal exposure differ in relation to the geographical location. Indeed, in some areas, toxicological health risks seem to be higher than in others: in Haiti, ground water shows $\mathrm{Pb}$ and $\mathrm{Cr}$ contamination [10], whereas significant levels of $\mathrm{As}, \mathrm{Pb}, \mathrm{Cd}$, $\mathrm{Ni}$, and $\mathrm{Cr}$ have been found in edible fish tissue in the Pearl River Delta in China [11]. Furthermore, environmental contaminants, for example, toxic metals such as aluminum (Al), are considered a possible cause of Alzheimer's disease [12].

1.1.3. Effects on Pregnancy and Childhood. Heavy metal exposure during pregnancy is potentially harmful to the developing fetus. A recent study focused on prenatal contamination by examining $\mathrm{Pb}, \mathrm{Hg}$, and $\mathrm{Cd}$ concentrations in blood samples from newborns (a specimen of umbilical-cord blood was drawn immediately after birth), pregnant women, and their partners in the Madrid Autonomous region [13]. In another study performed on pregnant women living in Eastern China, maternal blood and urine samples were obtained during the third trimester of pregnancy [14]. Parenteral transfer of $\mathrm{Cd}, \mathrm{Hg}$, and $\mathrm{Pb}$ by detecting them in maternal and cord blood samples (plasma and red blood cells), as well as in child postnatal blood samples of some African American mother-infant pairs randomly selected from the Boston Birth Cohort, was studied [15]. These works provide support for tobacco smoke and fish consumption as important preventable sources of heavy metal exposure in newborns.

1.2. Effects on Organs and Systems. Following toxic-metal exposure, many body organs and/or systems can be damaged [16]. The primary target organs of elemental $\mathrm{Hg}$ are the brain and the kidneys [17]. Childhood Cd exposure seems to adversely affect kidney function in rural Bangladesh [18]. Exposure to $\mathrm{As}, \mathrm{Cd}, \mathrm{Pb}$, and $\mathrm{Hg}$ has been shown to produce some deleterious effects on the hematological system [19]. Pb and $\mathrm{Cd}$ affect blood, liver, and kidneys through the induction of oxidative stress [6]. In addition, since the brain is an organ that is especially vulnerable to the effects of ROS because of its oxygen demand and its abundance of perioxidationsusceptible lipid cells, the role of ROS in the pathophysiology of neurodegenerative diseases (ND) seems to be central [20].

1.3. Effects on Cells. Many dangerous effects of toxic metals have been reported at human cellular level. Indeed, $\mathrm{Pb}$ is known to alter the membrane composition of phospholipids in human erythrocytes, to inhibit transmethylation, and to exasperate phospholipid peroxidative damage [21]. $\mathrm{Pb}$ induced neurodegeneration has been tested in neuronal PC12 cells that developed oxidative stress and apoptosis, aggravated by ethanol coexposure [22]. Pb damage on PC12 cells was propagated to neighboring cells through ROS-mitochondriadependent apoptotic signaling via gap-junctional intercellular communication [23]. Heavy metal-induced alterations on kidney intercellular junctions have been also reported [24].

Considering the serious damage to human health caused by toxic-metal exposure, we should examine how this contamination can be determined in humans.

\section{Assessment of Toxic-Metal Presence in Humans}

Inductively Coupled Plasma Mass Spectrometry (ICP-MS) is the method currently used to evaluate toxic-metal levels in blood and/or urine samples in humans. The same method has been efficiently used to evaluate metal concentrations in hair samples [25].

After "acute" intoxication, determination of toxic metals in blood and urine samples represents a useful tool to assess the presence of such metals in humans. Strong correlation has been found between $\mathrm{Cd}$ in kidney and $\mathrm{Cd}$ in urine and blood in an environmental exposed population [26]. As reported for $\mathrm{Hg}$ species, rats exposed to thimerosal or methylmercury by gavage displayed high blood levels of total $\mathrm{Hg}$, which progressively reduced from 6 to 120 hours after exposure. Tissues collected the fifth day after exposure revealed different forms of $\mathrm{Hg}$ (inorganic, methylmercury, or ethylmercury) in brain, liver, heart, and kidney [27]. However, the increase of blood toxic-metal values reflects only recent acute exposure, as seen for $\mathrm{Pb}$ [28]. Toxic metals rapidly move from the blood to many tissues where they are distributed, such as in the central nervous system (CNS). Accumulated metals can remain therein for many years, adversely affecting cell and tissue function. To remove sequestered toxic metals from the blood (where toxic metals accumulate following acute exposure) or human organs (where the same metals accumulate following chronic exposure) the only way is to bind such metals to chelating agents, with the aim of forming complexes. The routes of administration are oral, intramuscular (IM), and intravenous (IV). The complexes can be excreted especially by the kidneys. Indeed, toxic-metal levels can be examined in urine samples collected from patients, following the "challenge" with an opportune chelating agent.

Once the presence of toxic metals due to acute or chronic exposure has been determined, a second question arises: how can we remove these contaminating toxic metals? The 
most effective ways seem once again to be oral, IM, or IV administration of chelating agents to favor the elimination of toxic metals in the urine or in the faeces through the bile route. Chelation therapy plays a central role in modern medicine and pharmacology. Continuous studies with laboratory animals and extensive clinical experience show that acute or chronic intoxication with a variety of metals can be considerably improved by the administration of a suitable chelating agent [29]. As EDTA is able to bind $\mathrm{Fe}^{+++}$but not $\mathrm{Fe}^{++}$[30], in this review we have considered chelators able to remove iron excess, due to the clinical consequences of its overload, also in consideration of the role of $\mathrm{Fe}$ in neurodegeneration.

\section{Chelating Agents}

3.1. Iron (Fe) Excess in Thalassemia and ND. Acute Fe intoxication has been treated successfully with chelation therapy using deferoxamine. A woman who ingested ferrous sulphate in a suicide attempt was treated with the specific iron chelator deferoxamine, which binds ferric iron forming a water-soluble compound that is rapidly excreted by the kidney causing urine discoloration [31]. The important problems related to chronic Fe-overload observed in thalassemia patients can be overcome using chelating agents such as deferiprone, deferasirox, and deferoxamine [32]. Recently, combined treatment with oral deferiprone and subcutaneous desferoxamine twice weekly was shown to be a safe and effective alternative to chelation monotherapy in transfusion-dependent beta-thalassemia children [33]. The use of combined Fe chelators to prevent Fe-overload cardiomyopathy in thalassemia has been reported [34, 35]. Moreover, deferiprone is considered similar to deferoxamine in the treatment of thalassemia intermedia [36]. In addition, it has been shown that the oral Fe chelator deferasirox is able to inhibit NF- (nuclear factor-) $\mathrm{kB}$ dependent transcription without affecting its proximal activation, resulting in reduced TNF production from $\mathrm{T}$ cells stimulated in vitro. These results suggest that the hematopoietic improvement observed in deferasirox-treated patients affected by myelodysplasia and aplastic anemia might reflect an anti-inflammatory effect mediated through inhibition of the transcription factor NF$\mathrm{kB}$ and support the therapeutic targeting of this pathway [37].

Much evidence has now been accumulated regarding the involvement of $\mathrm{Fe}$ in various ND as well as potential therapy with $\mathrm{Fe}$ chelators to retard their progression [38]. With ageing, there is an elevation of brain Fe (within ferritin and neuromelanin) with no apparent adverse effects in the frontal cortex, caudate nucleus, putamen, substantia nigra, and globus pallidus. However, excessive amounts of Fe in these specific regions, or in specific intracellular compartments of the brain, lead to ND. Indeed, redox-active metal ions, such as $\mathrm{Fe}$ and copper $(\mathrm{Cu})$, can generate oxidative stress through production of ROS and nitrogen species. The one-electron reduction of $\mathrm{H}_{2} \mathrm{O}_{2}$ by $\mathrm{Fe}^{2+}$ (the well- known Fenton reaction) produces $\mathrm{Fe}^{3+}$ and the hydroxyl radical $\mathrm{OH}^{\bullet}$, which can react with a wide number of cellular constituents. This results in protein misfolding, amyloid production, and the formation of insoluble protein aggregates contained within inclusion bodies. Dysregulation of Fe metabolism, associated with cellular damage and oxidative stress, is reported as a common event in Alzheimer's disease (AD) and Parkinson's disease (PD) [39]. This will activate microglia, leading to neuroinflammation, which plays an important role in the progression of ND as activated microglia release proinflammatory cytokines that can damage neuronal cells. The evidence for metal involvement in PD and AD, as well as Friedreich's ataxia and multiple sclerosis (MS), suggests study of the effects of Fe chelators in patients affected by these diseases [38]. Brain Fe homeostasis is increasingly being recognized as a potential target for the development of drug therapy in age-related disorders. Deferiprone slightly improved motor symptoms in PD patients after 12 months of treatment, while the Fe content in the substantia nigra significantly decreased on magnetic resonance imaging (MRI) evaluation [40].

Excessive Fe can be toxic, and its accumulation in MS patients is generally thought to be detrimental. However, Fe maintains oligodendrocyte and myelin integrity and facilitates their regeneration following injury. The extracellular matrix, a key regulator of remyelination, might also regulate Fe levels. Histological and MRI studies have investigated changes in Fe distribution associated with MS. Treatment targeting Fe in MS patients must balance the trophic and toxic properties of Fe, providing sufficient Fe levels for remyelination and repair, while avoiding excesses that might overwhelm homeostatic mechanisms and contribute to damage [41]. In MS patients, the role of Fe in neurodegeneration has been highlighted, suggesting the use of Fe chelators together with neuroinflammation inhibitors [41].

3.2. Toxic-Metal Excess. The toxic metals that most frequently induce burdens in humans are $\mathrm{Pb}, \mathrm{Al}, \mathrm{Hg}, \mathrm{Cd}, \mathrm{As}$, and $\mathrm{Ni}$.

Other less-common toxic metals are antimony $(\mathrm{Sb})$, barium (Ba), beryllium (Be), bismuth (Bi), cesium (Cs), gadolinium $(\mathrm{Gd})$, palladium $(\mathrm{Pd})$, platinum $(\mathrm{Pt})$, tellurium (Te), thallium (Tl), thorium (Th), tin (Sn), tungsten (W), and uranium $(\mathrm{U})$; $\mathrm{Cr}$ is a carcinogenic heavy metal responsible for DNA damage and mutations [42]. Table 1 reports (for each toxic metal) the target organs and/or apparatus, the sources of toxic metals (which are always represented by ingestion, inhalation, or dermal absorption; of note, gadolinium, when used as contrast agent, and platinum, when used as chemotherapeutic agent, could be IV administered), and the toxic doses of each metal. Table 2 reports the most important intoxication symptoms and diseases.

3.3. Chelating Agents. Many agents were used in the past to remove metal intoxications, such as penicillamine, British anti-Lewisite (BAL or Dimercaprol), 2,3-dimercapto-1-propane sulfonic acid (Unithiol, DMPS), and meso-2,3-dimercaptosuccinic acid (Succimer, DMSA), other than EDTA. $\mathrm{D}$-Penicillamine has been used to remove $\mathrm{Hg}, \mathrm{Pb}$, and $\mathrm{Cd}$ other than $\mathrm{Cu}$ in excess [43] and in association with DMPS in Wilson's disease [44]. BAL has been used in the management of heavy metal poisoning. In poisoning cases 


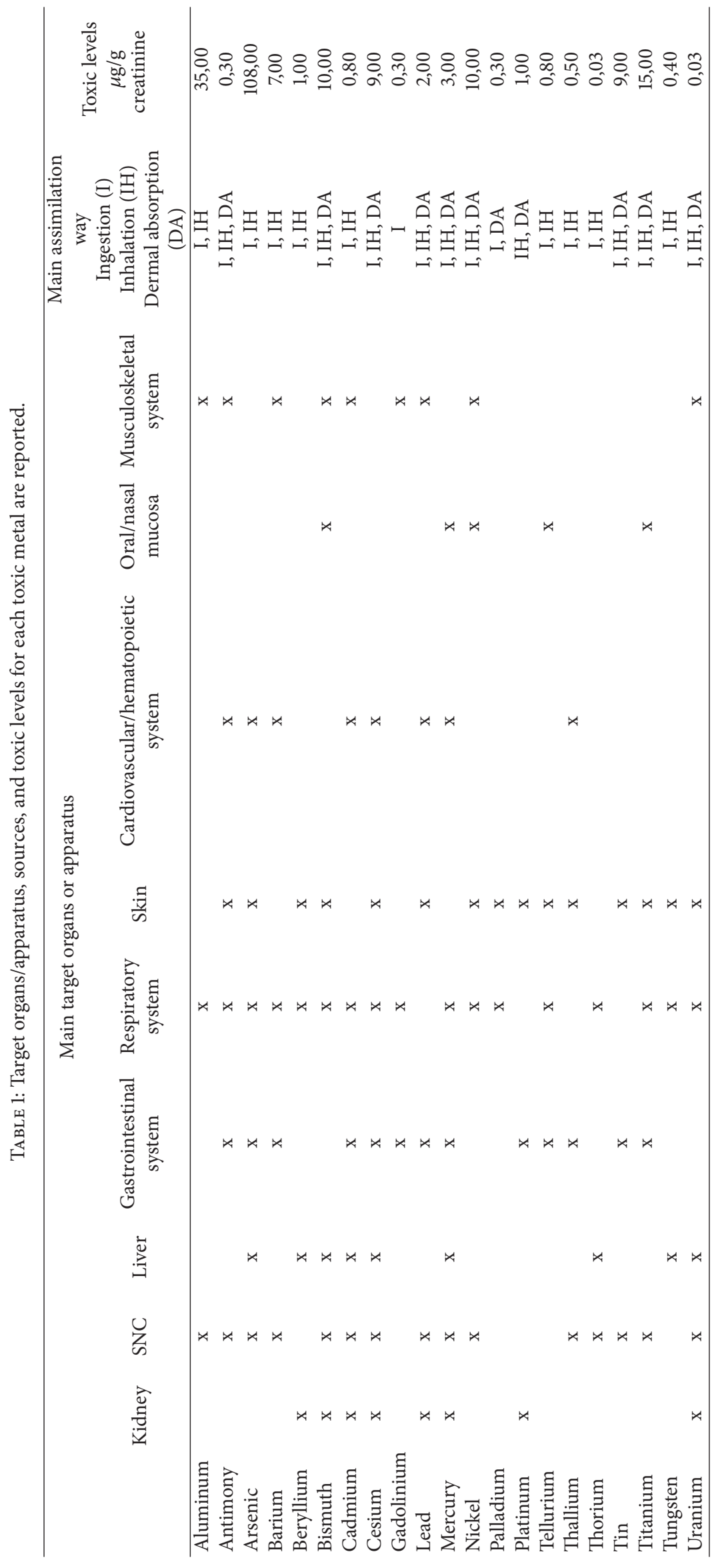


TABLE 2: The more common symptoms and/or diseases developed following intoxication are reported for each toxic metal. These are a free postediting from Zhou et al. [16].

\begin{tabular}{|c|c|}
\hline & Symptoms and diseases \\
\hline Aluminum & Fatigue, hypophosphatemia, increased prothrombin time, and porphyria. \\
\hline Antimony & $\begin{array}{l}\text { Nausea, anorexia, metallic taste, fatigue, and muscle weakness. Hypotension, cardiac pain (like angina pectoris), } \\
\text { and faulty ventricular polarization. Irritation of respiratory tissues, pneumoconiosis. "Antimony spots" on the } \\
\text { skin. }\end{array}$ \\
\hline Arsenic & $\begin{array}{l}\text { Fatigue, malaise. Eczema or allergic-like dermatitis. Skin hypopigmentation, white striae on fingernails, hair } \\
\text { loss, and stomatitis. Increased salivation and garlic-like breath. Peripheral neuropathy. Myocardial damage, } \\
\text { hemolysis, and aplastic anemia with leukopenia. }\end{array}$ \\
\hline Barium & $\begin{array}{l}\text { Tingling in the extremities, abnormal reflexes, and paralysis. Vomiting, diarrhea. Arrhythmia, hypertension. } \\
\text { Respiratory arrest/failure. }\end{array}$ \\
\hline Beryllium & $\begin{array}{l}\text { Hypoproteinemia, anemia. Liver and kidney damage. Chest pain, cough, and fatigue. } \\
\text { Granulomatous, lung disease, lung cancer. }\end{array}$ \\
\hline Bismuth & $\begin{array}{l}\text { Constipation or bowel irregularity, colitis. Foul breath. Skin pigmentation changes and gum pigmentation } \\
\text { (blue-black), gingivitis, and stomatitis. Erythema and skin sores, irritation of mucous membranes. Nephritis, } \\
\text { nephrosis, and hepatitis. "Bismuth encephalophy" with mental confusion, clumsiness, myoclonic jerks, tremors, } \\
\text { and dysarthria (osteoarthropathy). }\end{array}$ \\
\hline Cadmium & $\begin{array}{l}\text { Hypertension. Microcytic-hypochromic anemia (not responsive to iron supplementation). Proteinuria with } \\
\text { abnormally high excretion of beta- } 2 \text { microglobulin. }\end{array}$ \\
\hline Cesium & Ventricular arrhythmias, cardiotoxicity. Headache, nausea, and epileptic seizures. \\
\hline Gadolinium & $\begin{array}{l}\text { Abdominal cramps, diarrhea. Lethargy, muscular spasms, and respiratory collapse. Irritation of the skin and } \\
\text { eyes. }\end{array}$ \\
\hline Lead & $\begin{array}{l}\text { Loss of appetite, constipation. Poor hemoglobin synthesis, anemia. Nephrotoxic effects with impaired renal } \\
\text { excretion of uric acid. Tremors, neuropathy, and encephalopathy. }\end{array}$ \\
\hline Mercury & $\begin{array}{l}\text { Decreased senses of touch, hearing, vision, and taste, metallic taste in mouth. Fatigue or lack of physical } \\
\text { endurance. Increased salivation. Anorexia, numbness and paresthesias, headaches, irritability, and excitability. } \\
\text { Tremors and incoordination, psychoses, and manic behaviors. Anemia. Hypertension. }\end{array}$ \\
\hline Nickel & $\begin{array}{l}\text { Headache, vertigo. Muscle weakness. Nausea, vomiting. Palpitations. Itchy skin and dermatitis, eczema. } \\
\text { Panallergy with asthma, conjunctivitis, rhinitis, and sinusitis. }\end{array}$ \\
\hline Palladium & Skin, eye, and respiratory irritation and allergic contact dermatitis. \\
\hline Platinum & $\begin{array}{l}\text { Nausea, vomiting. Dyspnea and wheezing. Dermatitis, development of chronic allergic reactions ("platinosis"). } \\
\text { Nephrosis. Anemia, thrombocytopenia, and leukopenia. }\end{array}$ \\
\hline Tellurium & $\begin{array}{l}\text { Eye and respiratory irritation. Drowsiness, headache. Dry mouth, metallic taste, garlic-like odor of breath, } \\
\text { sweat, and urine. Abdominal pain, nausea, vomiting, and anorexia. Respiratory depression. Circulatory } \\
\text { collapse. Bluish/black patches on the skin. }\end{array}$ \\
\hline Thallium & $\begin{array}{l}\text { Nausea, gastrointestinal distress, diarrhea, and weight loss. Proteinuria. Fatigue. Mental confusion, memory } \\
\text { loss, psychoses, and peripheral neurological signs: paresthesias, myalgias, tremor, and ataxia. Hair loss with } \\
\text { sparing of pubic and body hair and a lateral fraction of eyebrows, alopecia. }\end{array}$ \\
\hline Thorium & Respiratory distress and pneumonia, pulmonary hypertension, and fibrosis. \\
\hline Tin & $\begin{array}{l}\text { Reduced sense of smell, headache, fatigue, ataxia, and muscle weakness. Irritation of contacted tissues (eyes, } \\
\text { skin, bronchial tubes, or gastrointestinal tract). }\end{array}$ \\
\hline Titanium & $\begin{array}{l}\text { Chest tightness and respiratory difficulty. Eye skin irritation. Neuroinflammation by titanium dioxide } \\
\text { nanoparticles. Hypersensitivity reaction. }\end{array}$ \\
\hline Tungsten & Lung diseases (pneumoconiosis, cancer). Eczema, pruritus, folliculitis, and neurodermatitis. \\
\hline Uranium & $\begin{array}{l}\text { Fatigue. Hair loss, alopecia, and dermatitis. Increased locomotor activity. Perturbation of the sleep-wake cycle, } \\
\text { decreased memory, and increased anxiety. }\end{array}$ \\
\hline
\end{tabular}

with elemental and inorganic Hg salts, BAL may be administered IM. DMSA and DMPS are administered orally or with IV injection and are currently used as chelating agents in $\mathrm{Hg}$ poisoning [45].

The human burden of all the reported toxic metals can be highlighted with the chelating agent EDTA using the socalled "chelation test." As an acid, EDTA (ethylenediaminetetraacetic acid) has been used in clinical ophthalmology to treat band-shaped keratopathy [46]. In current clinical practice, it exists as sodium edetate $\left(\mathrm{Na}_{2}\right.$ EDTA) and as calcium disodium edetate ( $\left.\mathrm{CaNa}_{2} \mathrm{EDTA}\right)$, which is frequently reported as CaEDTA. The "challenge" with EDTA or the "chelation test" highlights the presence of toxic metals in urine samples recovered from patients. Patients are invited to collect urine samples before and after intravenous treatment with the chelating agent $\mathrm{CaNa}_{2}$ EDTA $(2 \mathrm{~g} / 10 \mathrm{~mL}$ diluted in $500 \mathrm{~mL}$ physiological saline), referred to in the present paper as EDTA. EDTA is slowly administered intravenously (infusion lasts about 2 hours) and the time of urine collection following chelation lasts $12 \mathrm{~h}$. Toxic-metal urine contents are expressed in micrograms $(\mu \mathrm{g})$ per g creatinine [47]. Details regarding "chelation test" have already been reported [48].

3.4. Usefulness of EDTA as Chelating Agent in Clinical Practice. The following cases reported in the literature confirm the 
TABLE 3: Characteristics of chelating agents used in clinical practice.

\begin{tabular}{|c|c|c|c|c|}
\hline & $\begin{array}{c}\text { Route of } \\
\text { administration } \\
\end{array}$ & Adult dose & $\begin{array}{c}\text { Route of metal } \\
\text { complex excretion }\end{array}$ & Side effects \\
\hline BAL & IM & $5 \mathrm{mg} / \mathrm{kg} /$ day & $\begin{array}{l}\text { Urine, bile, faeces, } \\
\text { lungs }\end{array}$ & $\begin{array}{l}\text { Nausea, vomiting, } \\
\text { hypertension, } \\
\text { tachycardia, } \\
\text { headache }\end{array}$ \\
\hline Deferiprone & Oral & $50-100$ mg/kg/day & Urine & $\begin{array}{c}\text { CNS toxicity, } \\
\text { lenticular opacities, } \\
\text { arthropathy }\end{array}$ \\
\hline \multirow{2}{*}{ Deferoxamine } & IV & $50 \mathrm{mg} / \mathrm{kg} /$ day & \multirow{2}{*}{ Urine } & \multirow{2}{*}{$\begin{array}{c}\text { Nausea, weight } \\
\text { loss, ocular toxicity }\end{array}$} \\
\hline & Subcutaneously & $20 \mathrm{mg} / \mathrm{kg} /$ day & & \\
\hline Deferasirox & Oral & 35 mg/kg/day & Faeces, urine & $\begin{array}{l}\text { Abdominal pain, } \\
\text { nausea, vomiting, } \\
\text { elevation of liver } \\
\text { enzymes }\end{array}$ \\
\hline \multirow{3}{*}{ DMPS } & Oral & $\begin{array}{c}300 \mathrm{mg} \text { three times } \\
\text { a day }\end{array}$ & \multirow{3}{*}{ Urine } & \multirow{3}{*}{$\begin{array}{l}\text { Rash, nausea, } \\
\text { leukopenia }\end{array}$} \\
\hline & IV & until 1500 mg/day & & \\
\hline & IM & $20 \mathrm{mg} / \mathrm{kg} /$ day & & \\
\hline \multirow{2}{*}{ DMSA } & Oral & $30 \mathrm{mg} / \mathrm{kg} /$ day & $\begin{array}{l}\text { Urine, bile, faeces, } \\
\text { lungs }\end{array}$ & \multirow{2}{*}{$\begin{array}{c}\text { Gastrointestinal } \\
\text { disorders (GI), } \\
\text { skin rashes, flu-like } \\
\text { symptoms }\end{array}$} \\
\hline & IV & $\begin{array}{c}10 \mathrm{mg} / \mathrm{kg} \text { three } \\
\text { times a day }\end{array}$ & & \\
\hline EDTA & IV & $2 \mathrm{gr} /$ week & Urine & None $^{*}$ \\
\hline D-Penicillamine & Oral & $5-20 \mathrm{mg} / \mathrm{kg} /$ day & Urine & $\begin{array}{c}\text { Degenerative } \\
\text { dermopathy, } \\
\text { thromboleukocy- } \\
\text { topenia, } \\
\text { GI }\end{array}$ \\
\hline
\end{tabular}

* When used once a week at the dose reported and intravenously injected in about 2 hours.

DMPS: 2,3-dimercapto-1-propane sulphonic acid.

DMSA: meso-2,3-dimercaptosuccinic acid.

EDTA: $\mathrm{CaNa}_{2}$ ethylenediaminetetraacetic acid.

usefulness of EDTA in clinical practice. In 1997, severe lead poisoning in humans was reported in rural Albania. Twentythree people exhibiting signs of lead intoxications recovered following intensive CaEDTA chelation therapy [49]. EDTA chelation therapy was used by French researchers, in association with USA researchers, to remove contaminating metals and to decrease free-radical production in humans, as reported in a study published in 2005 [50]. The authors showed that the addition of high-dose $(5 \mathrm{~g})$ vitamin $\mathrm{C}$ to EDTA chelation solutions induced acute prooxidant effect, as monitored by lipid, protein, and DNA oxidative markers, but that long treatment (e.g., multiple sessions of EDTA chelation therapy) protected against oxidative damage, despite the presence of vitamin C. Moreover, in 2009 the French group showed that EDTA chelation therapy, without added vitamin C, decreased oxidative DNA damage and lipid peroxidation [51]. CaEDTA was used to avoid damage from acute $\mathrm{Pb}$ poisoning in an infant who received traditional Omani medicine (which was found to contain high $\mathrm{Pb}$ ) for constipation [52]. Successful treatment with EDTA of extreme acute lead intoxication in a child was carried out in the Slovak Republic [53]. More recently, in Italy chelation with EDTA was successfully used to treat four patients exposed to occupational poisoning in two Chinese battery recycling plants [54]. The use of CaEDTA, rather than $\mathrm{Na}_{2}$ EDTA, seems to be safer in the treatment of lead-intoxicated children [55]. CaEDTA chelation therapy has been used to remove $\mathrm{Cd}$ intoxication in association with reduced glutathione (GSH) [56]. GSH plays a key role in cell resistance against oxidative damage by providing enzymes involved in ROS metabolism with reducing equivalents, by eliminating potentially toxic oxidation products, and by reducing oxidized protein thiols [57]. Recently, we showed that $\mathrm{CaNa}_{2}$ EDTA treatment of patients affected by $\mathrm{Al}$ burden significantly reduced $\mathrm{Al}$ intoxication [48]. Moreover, the efficacy of long-term chelation therapy has been shown in the removal of chronic Al intoxication [58]. Table 3 reports the more important clinical features of chelating agents. EDTA at the dose of $2 \mathrm{~g} /$ week with slow IV infusion (over around 2 hours) did not produce side effects in humans. In the past, when $\mathrm{Na}_{2}$ EDTA was used at the dose of 
$6 \mathrm{~g} /$ week, an increase in parathyroid hormone and a decrease in serum bone alkaline phosphatase were seen [59]. At the dose of $2 \mathrm{~g}$ once a week, in my experience EDTA has no side effects.

\section{Usefulness of EDTA Chelation Therapy in Cardiovascular Diseases (CVD) and Neurodegenerative Diseases (ND)}

4.1. CVD. $\mathrm{Na}_{2}$ EDTA is considered more able to chelate $\mathrm{Ca}^{++}$ than $\mathrm{CaNa}_{2}$ EDTA and has been used to treat atherosclerosis, chronic inflammation related to endothelial dysfunction, as EDTA is thought to operate by scavenging calcium from fatty plaques. Indeed, EDTA chelation therapy using $\mathrm{Na}_{2}$ EDTA has been used in the past and is still used today, to treat patients with coronary disease [60].

A recent trial assessed that in stable postmyocardial infarction patients the combination of oral high-dose vitamins and EDTA chelation therapy, compared with a double placebo, reduced clinically important cardiovascular events to an extent that was both statistically significant and of potential clinical relevance [61]. Chelation infusion contents contained a variable dose of ethylenediaminetetraacetic acid up to a maximum of $3 \mathrm{~g}$ depending on estimated glomerular filtration rate and were $\mathrm{Na}_{2}$ EDTA based. A regimen of 40 infusions was carried out [62]. The results of this clinical trial (which showed that a metal chelator reduced cardiovascular events) highlight the potential connection between metal pollutants and $\mathrm{CVD}$. Indeed, $\mathrm{Hg}, \mathrm{Pb}, \mathrm{Cd}$, and $\mathrm{As}$ have been shown to display epidemiologic and mechanistic links to atherosclerosis and CVD, suggesting that environmental metal pollution might be a potent and modifiable risk factor for atherosclerotic disease [63]. Epidemiological evidence suggests that $\mathrm{Cd}$ and As exposure are associated with CVD incidence and mortality $[63,64]$. Diabetes mellitus is a wellknown risk factor for early CVD. EDTA chelation affects both transition and toxic metals. In fact, transition metals like $\mathrm{Cu}$ and $\mathrm{Fe}$ play important roles in the oxidative stress pathway, which is involved in insulin resistance, whereas the metals $\mathrm{Pb}$ and $\mathrm{Cd}$ are particularly toxic for the cardiovascular system. Recent findings therefore suggest the use of EDTA chelation therapy in the treatment of CVD, especially in diabetic patients [65].

4.2. $N D$. The role of prenatal and postnatal exposure to environmental factors can lead to the onset of ND in later life. Neurotoxic metals such as $\mathrm{Pb}, \mathrm{Hg}, \mathrm{Al}, \mathrm{Cd}$, and As, as well as certain pesticides and metal-based nanoparticles, have been involved in $\mathrm{AD}$, due to their ability to increase beta-amyloid peptide and the phosphorylation of Tau protein, causing the senile amyloid plaques and neurofibrillary tangles that are characteristic of $\mathrm{AD}$. Exposure to $\mathrm{Pb}$, manganese $(\mathrm{Mn})$, solvents, and pesticides has been related to certain PD hallmarks, such as mitochondrial dysfunction, alterations in metal homeostasis, and the aggregation of alpha-synuclein proteins, a key constituent of Lewy bodies that are a crucial factor in PD pathogenesis [66]. Chronic methyl-Hg exposure causes symptoms similar to those observed in amyotrophic lateral sclerosis (ALS) and AD. Indeed, $\mathrm{Hg}$ and its salts are able to induce depletion of GSH, mitochondria breakage, and increased lipid peroxidation of protein and DNA in the brain [67]. EDTA chelation therapy, whose usefulness has been shown in the elimination of $\mathrm{Al}$ intoxication [48], can therefore be recommended for the removal of other toxic metals responsible for ND development. The beneficial effect of EDTA treatment has been demonstrated by the neurological relief of symptoms such as spasticity, fatigue, and relapse in patients intoxicated by $\mathrm{Al}$ and affected by $\mathrm{ND}[48,58,68]$. EDTA has been shown to be useful in attenuating peripheral blood cell damage in workers exposed to $\mathrm{Pb}[69]$. The therapeutic effect of EDTA in experimental models of MS has been demonstrated, where EDTA was able to reduce demyelination plaques in intraperitoneally treated mice possibly in relation to the antioxidant and anti-inflammatory effects of EDTA [70].

\section{Kidney Protection in EDTA Treatment}

Cases of acute tubular necrosis have been reported following the early clinical use of EDTA involving very large doses [71]. At the doses now used clinically, EDTA effectively delays the progression of chronic kidney disease in patients with measurable body $\mathrm{Pb}$ burdens, as reflected by increased levels of estimated glomerular filtration rate and creatinine clearance rate [71].

EDTA treatment has been shown to slow down the progression of experimental $\mathrm{Pb}$ nephropathy [72]. Indeed, renal alteration produced in male Wistar rats during chronic $\mathrm{Pb}$ poisoning showed hypertrophy and vacuolization of medium and small arteries; mucoid edema and muscular hypertrophy in arterioles; loss of cell brush borders, cell loss, and intracellular inclusion bodies in the proximal tubules; fibrosis and the presence of infiltrates in the interstitial components. In rats treated intraperitoneally for five days with $\mathrm{CaNa}_{2} \mathrm{EDTA}$ such alterations were delayed. We previously demonstrated the efficacy of EDTA treatment in improving renal function in an experimental model of renal ischemia/reperfusion (I/R) [73]. Kidney $I / R$ is an endothelial injury similar to what occurs in coronary disease. Moreover, such kidney protection has been shown in humans. Many papers positively describe clinically prolonged EDTA treatment in patients affected by chronic renal diseases (affected or not by diabetes), following or not $\mathrm{Pb}$ intoxication [74-78]. More specifically, researchers have shown that (i) low-level environmental $\mathrm{Pb}$ exposure may accelerate progressive renal insufficiency in patients without diabetes suffering from chronic renal disease; (ii) low-level environmental $\mathrm{Pb}$ exposure accelerates progressive diabetic nephropathy, and $\mathrm{Pb}$-chelation therapy can decrease its rate of progression in patients with typeII diabetes; (iii) repeated chelation therapy might improve renal function and slow the progression of renal insufficiency in nondiabetic patients. Other toxic metals, such as $\mathrm{Cd}, \mathrm{Cr}$, $\mathrm{Hg}$, and $\mathrm{U}$, have previously been associated with nephropathy [79]. Noteworthily, all these metals are chelated by EDTA. 


\begin{tabular}{|c|c|c|c|c|}
\hline Metals & Result $\mu \mathrm{g} / \mathrm{g}$ creat & Within reference range & ELevated & Very elevated \\
\hline Antimony & 14300 & & & \\
\hline Antimony & 0,3 & & & \\
\hline Arsenic & $<\mathrm{dl}$ & & & \\
\hline Barium & 28 & & & \\
\hline Beryllium & 0,7 & & & \\
\hline Bismuth & $<\mathrm{dl}$ & & & \\
\hline Cadmium & 5,7 & & & \\
\hline Cesium & 1,8 & 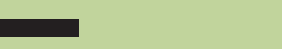 & & \\
\hline Gadolinium & 99 & & & \\
\hline Lead & 80 & & & \\
\hline Mercury & 2,6 & & & \\
\hline Nickel & 30 & & & \\
\hline Palladium & 0,4 & & & \\
\hline Platinum & $<\mathrm{dl}$ & & & \\
\hline Tellurium & $<\mathrm{dl}$ & & & \\
\hline Thallium & 0,7 & & & \\
\hline Thorium & 0,8 & & & \\
\hline Tin & 17 & & & \\
\hline Titanium & N/A & & & \\
\hline Tungsten & 0,6 & & & \\
\hline Uranium & 0,6 & & & \\
\hline
\end{tabular}

FIGURE 1: Toxic-metal levels measured in the patient's urine collected during the 12 hours following EDTA "challenge" (chelation test) reported in micrograms $(\mu \mathrm{g})$ per g creatinine. The 48 -year-old female patient was affected by multiple sclerosis.

\section{Passage of EDTA across the Blood-Brain Barrier}

Some authors maintain that EDTA cannot cross the bloodbrain barrier. Passage across the blood-brain barrier is physiologically possible into the circumventricular organs. However, new transport concepts for molecules and cells (inflammatory and neoplastic) under inflammatory conditions have been reported [80]. More recently, clearance of amyloid-beta peptide across the blood-brain barrier, the ability of an encephalic arbovirus to cross the same barrier, and barrier disruption by the streptococcus responsible for neonatal meningitis have been described [81-83]. If viruses, bacteria, and metastatic and inflammatory cells can cross the blood-brain barrier why can EDTA not cross it? Neuroinflammation in patients with ND relates to cytokinedependent increase of blood-brain barrier permeability. Such a condition is possibly present also in healthy patients following pathogenic infection. The amelioration of neurologic symptoms in patients affected by ND treated with Fe chelators suggests they can cross the blood-brain barrier and remove iron deposition in the brain [38]. EDTA has a molecular weight lower than that of deferoxamine, an important iron chelator for thalassemia patients, and it is feasible that EDTA also can cross the blood-brain barrier especially in patients with neuroinflammation. In a recent paper, Louveau et al. describe the discovery of the CNS lymphatic system (functional lymphatic vessels lining the dural sinuses). These structures express all of the molecular hallmarks of lymphatic endothelial cells, are able to carry both fluid and immune cells from the cerebrospinal fluid, and are connected to the deep cervical lymph nodes. This discovery sheds new light on the etiology of neuroinflammatory diseases and ND [84] and possible new therapeutic strategies.

\section{Usefulness of EDTA to Chelate Toxic Metals}

Many papers report that EDTA is able to chelate $\mathrm{Pb}, \mathrm{Cd}$, zinc $(\mathrm{Zn})$, and $\mathrm{Ca}$. The EDTA-metal chelate is water soluble and is typically excreted in the urine. It can form strong covalent bonds with the metals and increase urinary excretion. EDTA can chelate all toxic metals, as shown in two urine mineralograms reported as examples (Figures 1 and 2). Figure 1 shows toxic-metal values in urine samples taken after chelation test and expressed as $\mu \mathrm{g}$ per g creatinine, from a 48 -year-old female patient affected by MS. Elevated levels of $\mathrm{Ba}, \mathrm{Be}, \mathrm{Ni}$, $\mathrm{Pd}, \mathrm{Tl}, \mathrm{Sn}$, and $\mathrm{W}$ and extremely elevated levels of $\mathrm{Al}, \mathrm{Cd}$, $\mathrm{Gd}, \mathrm{Pb}$, Th, and $\mathrm{U}$ are highlighted. Figure 2 shows toxicmetal values in urine samples taken from a 61-year-old male 


\begin{tabular}{|c|c|c|c|c|}
\hline Metals & Result $\mu \mathrm{g} / \mathrm{g}$ creat & Within reference range & Elevated & Very elevated \\
\hline Antimony & 240 & & & \\
\hline Antimony & 4,2 & & & \\
\hline Arsenic & 400 & & & \\
\hline Barium & 28 & & & \\
\hline Beryllium & $<\mathrm{dl}$ & & & \\
\hline Bismuth & $<\mathrm{dl}$ & & & \\
\hline Cadmium & 33 & & & \\
\hline Cesium & 81 & & & \\
\hline Gadolinium & 420 & & & \\
\hline Lead & 330 & & & \\
\hline Mercury & 23 & & & \\
\hline Nickel & 110 & & & \\
\hline Palladium & $<\mathrm{dl}$ & & & \\
\hline Platinum & $<\mathrm{dl}$ & & & \\
\hline Tellurium & $<\mathrm{dl}$ & & & \\
\hline Thallium & 4 & & & \\
\hline Thorium & $<\mathrm{dl}$ & & & \\
\hline Tin & 5,9 & & & \\
\hline Titanium & $\mathrm{N} / \mathrm{A}$ & & & \\
\hline Tungsten & 0,7 & & & \\
\hline Uranium & 1 & & & \\
\hline
\end{tabular}

FIGURE 2: Toxic-metal levels measured in the patient's urine collected during the 12 hours following EDTA "challenge" (chelation test) reported in micrograms $(\mu \mathrm{g})$ per g creatinine. The 61-year-old male patient was affected by idiopathic progressive spastic paraparesis.

patient affected by idiopathic progressive spastic paraparesis. Elevated levels of $\mathrm{Ba}, \mathrm{Cs}, \mathrm{Sn}$, and $\mathrm{W}$ and extremely elevated levels of $\mathrm{Al}, \mathrm{Sb}, \mathrm{As}, \mathrm{Cd}, \mathrm{Gd}, \mathrm{Pb}, \mathrm{Hg}, \mathrm{Ni}$, Th, and $\mathrm{U}$ are highlighted. Before EDTA challenge, the urine samples did not reveal the presence of toxic metals (data not shown). The elevated intoxication (in terms of both highest levels of toxic metals and high number of toxic metals involved) shown by these two patients correlates with their serious clinical manifestations (extreme walking impairment, gait ataxia, leg and arm spasticity, paresthesia, disturbance of fine motor skills, etc.). The results displayed by more than 1,000 urine mineralograms show a constant relationship between highest toxic-metal burden and most serious symptoms of ND that were successfully improved by EDTA chelation therapy (personal unpublished data).

\section{Concomitant Treatment with Antioxidants}

Chelation therapy can be efficiently associated with daily antioxidant treatment to improve the endogenous detoxification ability of each patient. The use of antioxidant treatment can improve endogenous mechanisms endowed with antioxidant functions, especially in ND patients. The antioxidant treatments could be glutathione (Ultrathione, $500 \mathrm{mg} /$ day), alone or together with multivitamin complexes, amino acid and mineral mixtures, or probiotics. We have already shown how chelation therapy with $\mathrm{CaNa}_{2}$ EDTA, associated with the antioxidant compound Cellfood, can significantly improve the blood parameters of patients affected by ND, as well as those of unaffected healthy patients (controls) [68]. Indeed, after three-month chelation+Cellfood administration, oxidized LDL (oxLDL) decreased, ROS levels were significantly lower, and total antioxidant capacity (TAC) and glutathione levels were significantly higher than following chelation+other above reported antioxidant treatments. Moreover, homocysteine metabolism also improved in both groups (Cellfood and other antioxidants), also lasting three months both in ND patients and in controls. Cellfood (Eurodream, La Spezia, Italy) is an antioxidant nutritional supplement containing 78 ionic/colloidal trace elements and minerals combined with 34 enzymes and 17 amino acids, all suspended in a solution of deuterium sulphate that is efficient in protecting against damage in vitro [85]. In a previous study, it was shown that Cellfood treatment in vitro increased mitochondrial metabolism in endothelial cells [86]. New interest is emerging in the role of mitochondria in disease development and progression and also as a target for environmental toxicants. Respiratory dysregulation has been linked to cell death and helps increase the onset of neurodegenerative diseases, such as PD and AD. The 
mechanisms underlying the sensitivity of the mitochondrial respiratory complexes to redox modulation, as well as the effects of environmental contaminants that have mitochondrial toxicity, have recently been examined and discussed [87]. Protection of mitochondria against damage due to specific xenobiotics can be a useful tool to help avoid disease. The lack of significant studies on the efficacy of associated treatment using chelating agents and antioxidants to improve oxidative stress parameters in humans highlights the reported results.

\section{Concluding Remarks}

Recent research suggests that EDTA chelation may be a welltolerated and effective treatment method for postmyocardial infarction patients [88]. Toxic metals are pollutants that can represent cardiovascular risk factors and are involved in the development of vascular complications, especially in diabetic patients [89]. Indeed, EDTA chelation therapy can be promoted as treatment for heart disease, particularly in patients with diabetes [90]. Toxic metals also exert an important role in the pathogenesis of ND. EDTA chelation therapy has been shown to improve neurologic symptoms in ND patients $[48,68]$, and results are further enhanced by the use of antioxidants. EDTA chelation therapy, at the dose of $2 \mathrm{~g} /$ week slowly injected IV in adults, does not provoke side effects, can be used for a long period to ameliorate both acute and chronic intoxications, and is able to remove all toxic metals and reduce oxidative stress injury and inflammation in blood vessel walls $[50,51,60,65,73,90]$. EDTA treatment represents an important option in the treatment of ND and CVD associated with metal burden. No interaction is known regarding the drugs commonly used for CVD or ND with EDTA.

\section{Competing Interests}

The author declares that they have no competing interests.

\section{Acknowledgments}

The author would like to thank Michael John of the VitaSalute University in Milan for the English language editing of this paper and Dr. Alessandro Fulgenzi for his constant help in our experimental and clinical studies.

\section{References}

[1] M. Kampa and E. Castanas, "Human health effects of air pollution," Environmental Pollution, vol. 151, no. 2, pp. 362-367, 2008.

[2] R. K. Yadav, P. S. Minhas, K. Lal, R. K. Chaturvedi, G. Yadav, and T. P. Verma, "Accumulation of metals in soils, groundwater and edible parts of crops grown under long-term irrigation with sewage mixed industrial effluents," Bulletin of Environmental Contamination and Toxicology, vol. 95, no. 2, pp. 200-206, 2015.

[3] N. Brucker, A. Moro, M. Charão et al., "Relationship between blood metals and inflammation in taxi drivers," Clinica Chimica Acta, vol. 444, pp. 176-181, 2015.
[4] P. Fournier, J. Fourcade, J. Roncalli, R. Salvayre, M. Galinier, and E. Caussé, "Homocysteine in chronic heart failure," Clinical Laboratory, vol. 61, no. 9, pp. 1137-1145, 2015.

[5] M. C. Houston, "Role of mercury toxicity in hypertension, cardiovascular disease, and stroke," Journal of Clinical Hypertension, vol. 13, no. 8, pp. 621-627, 2011.

[6] V. Matović, A. Buha, D. Dukić-Ćosić, and Z. Bulat, "Insight into the oxidative stress induced by lead and/or cadmium in blood, liver and kidneys," Food and Chemical Toxicology, vol. 78, pp. 130-140, 2015.

[7] T. Wang, W. Feng, D. Kuang et al., "The effects of heavy metals and their interactions with polycyclic aromatic hydrocarbons on the oxidative stress among coke-oven workers," Environmental Research, vol. 140, pp. 405-413, 2015.

[8] A. Kasperczyk, M. Dziwisz, A. Ostałowska, E. Świętochowska, and E. Birkner, "Function of the liver and bile ducts in humans exposed to lead," Human and Experimental Toxicology, vol. 32, no. 8, pp. 787-796, 2013.

[9] K. H. Al-Gubory, "Environmental pollutants and lifestyle factors induce oxidative stress and poor prenatal development," Reproductive BioMedicine Online, vol. 29, no. 1, pp. 17-31, 2014.

[10] J. R. Schwartzbord, E. Emmanuel, and D. L. Brown, "Haiti's food and drinking water: a review of toxicological health risks," Clinical Toxicology, vol. 51, no. 9, pp. 828-833, 2013.

[11] H. M. Leung, A. O. W. Leung, H. S. Wang et al., "Assessment of heavy metals/metalloid (As, $\mathrm{Pb}, \mathrm{Cd}, \mathrm{Ni}, \mathrm{Zn}, \mathrm{Cr}, \mathrm{Cu}, \mathrm{Mn}$ ) concentrations in edible fish species tissue in the Pearl River Delta (PRD), China," Marine Pollution Bulletin, vol. 78, no. 1-2, pp. 235-245, 2014.

[12] M. Yegambaram, B. Manivannan, T. G. Beach, and R. U. Halden, "Role of environmental contaminants in the etiology of Alzheimer's disease: a review," Current Alzheimer Research, vol. 12, no. 2, pp. 116-146, 2015.

[13] E. García-Esquinas, B. Pérez-Gómez, P. Fernández-Navarro et al., "Lead, mercury and cadmium in umbilical cord blood and its association with parental epidemiological variables and birth factors," BMC Public Health, vol. 13, article 841, 2013.

[14] H. Sun, W. Chen, D. Wang, Y. Jin, X. Chen, and Y. Xu, "The effects of prenatal exposure to low-level cadmium, lead and selenium on birth outcomes," Chemosphere, vol. 108, pp. 33-39, 2014.

[15] Z. Chen, R. Myers, T. Wei et al., "Placental transfer and concentrations of cadmium, mercury, lead, and selenium in mothers, newborns, and young children," Journal of Exposure Science and Environmental Epidemiology, vol. 24, no. 5, pp. 537544, 2014.

[16] X. Zhou, S. W. Burchiel, and L. G. Hudson, "Conference summary and recent advances: the 8th Conference on Metal Toxicity and Carcinogenesis," Biological Trace Element Research, vol. 166, pp. 1-6, 2015.

[17] J.-D. Park and W. Zheng, "Human exposure and health effects of inorganic and elemental mercury," Journal of Preventive Medicine and Public Health, vol. 45, no. 6, pp. 344-352, 2012.

[18] H. Skröder, S. Hawkesworth, M. Kippler et al., "Kidney function and blood pressure in preschool-aged children exposed to cadmium and arsenic-potential alleviation by selenium," Environmental Research, vol. 140, pp. 205-213, 2015.

[19] N. Roney, H. G. Abadin, B. Fowler, and H. R. Pohl, "Metal ions affecting the hematological system," Metal Ions in Life Sciences, vol. 8, pp. 143-155, 2011. 
[20] G. H. Kim, J. E. Kim, S. J. Rhie, and S. Yoon, "The role of oxidative stress in neurodegenerative diseases," Experimental Neurobiology, vol. 24, no. 4, pp. 325-340, 2015.

[21] Shafiq-Ur-Rehman, "Effect of lead on lipid peroxidation, phospholipids composition, and methylation in erythrocyte of human," Biological Trace Element Research, vol. 154, no. 3, pp. 433-439, 2013.

[22] V. Kumar, V. K. Tripathi, S. Jahan et al., "Lead intoxication synergies of the ethanol-induced toxic responses in neuronal cells-PC12," Molecular Neurobiology, vol. 52, no. 3, pp. 15041520, 2015.

[23] S. Guo, J. Zhou, X. Chen et al., "Bystander effects of PC12 cells treated with $\mathrm{Pb}^{2+}$ depend on ROS-mitochondria-dependent apoptotic signaling via gap-junctional intercellular communication," Toxicology Letters, vol. 229, no. 1, pp. 150-157, 2014.

[24] J. L. Reyes, E. Molina-Jijón, R. Rodríguez-Muñoz, P. BautistaGarcía, Y. Debray-García, and M. D. C. Namorado, "Tight junction proteins and oxidative stress in heavy metals-induced nephrotoxicity," BioMed Research International, vol. 2013, Article ID 730789, 14 pages, 2013.

[25] E. Blaurock-Busch, Y. M. Busch, A. Friedle, H. Buerner, C. Parkash, and A. Kaur, "Comparing the metal concentration in the hair of cancer patients and healthy people living in the Malwa region of Punjab, India," Clinical Medicine Insights: Oncology, vol. 8, pp. 1-13, 2014.

[26] M. Akerstrom, L. Barregard, T. Lundh, and G. Sallsten, "The relationship between cadmium in kidney and cadmium in urine and blood in an environmentally exposed population," Toxicology and Applied Pharmacology, vol. 268, no. 3, pp. 286-293, 2013.

[27] J. L. Rodrigues, J. M. Serpeloni, B. L. Batista, S. S. Souza, and F. Barbosa Jr., "Identification and distribution of mercury species in rat tissues following administration of thimerosal or methylmercury," Archives of Toxicology, vol. 84, no. 11, pp. 891896, 2010.

[28] A. Rosin, "The long-term consequences of exposure to lead," Israel Medical Association Journal, vol. 11, no. 11, pp. 689-694, 2009.

[29] E. J. Baran, "Chelation therapies: a chemical and biochemical perspective," Current Medicinal Chemistry, vol. 17, no. 31, pp. 3658-3672, 2010.

[30] T. J. Magliery, L. K. Vitellaro, N. K. Diop, and R. A. Marusak, "Fe-EDTA-bisamide and Fe-ADR-925, the iron-bound hydrolysis product of the cardioprotective agent dexrazoxane, cleave DNA via the hydroxyl radical," Metal-Based Drugs, vol. 4, no. 4, pp. 199-205, 1997.

[31] S. Fernández, P. Castro, S. Nogué, and J. M. Nicolás, "Acute iron intoxication: change in urine color during chelation therapy with deferoxamine," Intensive Care Medicine, vol. 40, article 104, 2014.

[32] N. Arandi, S. Haghpanah, S. Safaei et al., "Combination therapy-deferasirox and deferoxamine-in thalassemia major patients in emerging countries with limited resources," Transfusion Medicine, vol. 25, no. 1, pp. 8-12, 2015.

[33] D. Songdej, N. Sirachainan, P. Wongwerawattanakoon et al., "Combined chelation therapy with daily oral deferiprone and twice-weekly subcutaneous infusion of desferrioxamine in children with $\beta$-thalassemia: 3-year experience," Acta Haematologica, vol. 133, no. 2, pp. 226-236, 2015.

[34] V. Berdoukas, T. D. Coates, and Z. I. Cabantchik, "Iron and oxidative stress in cardiomyopathy in thalassemia," Free Radical Biology and Medicine, vol. 88, pp. 3-9, 2015.
[35] S. Wongjaikam, S. Kumfu, S. C. Chattipakorn, S. Fucharoen, and N. Chattipakorn, "Current and future treatment strategies for iron overload cardiomyopathy," European Journal of Pharmacology, vol. 765, pp. 86-93, 2015.

[36] G. Calvaruso, A. Vitrano, R. Di Maggio et al., "Deferiprone versus deferoxamine in thalassemia intermedia: results from a 5-year long-term Italian multicenter randomized clinical trial," American Journal of Hematology, vol. 90, no. 7, pp. 634-638, 2015.

[37] A. Banerjee, N. A. Mifsud, R. Bird et al., "The oral iron chelator deferasirox inhibits NF- $\kappa$ B mediated gene expression without impacting on proximal activation: implications for myelodysplasia and aplastic anaemia," British Journal of Haematology, vol. 168 , no. 4, pp. 576-582, 2015.

[38] R. J. Ward, D. T. Dexter, and R. R. Crichton, "Neurodegenerative diseases and therapeutic strategies using iron chelators," Journal of Trace Elements in Medicine and Biology, vol. 31, pp. 267-273, 2015.

[39] A. A. Belaidi and A. I. Bush, "Iron neurochemistry in Alzheimer's disease and Parkinson's disease: targets for therapeutics," Journal of Neurochemistry, vol. 139, no. 1, pp. 179-197, 2016.

[40] D. Devos, C. Moreau, J. C. Devedjian et al., "Targeting chelatable iron as a therapeutic modality in Parkinson's disease," Antioxidants and Redox Signaling, vol. 21, no. 2, pp. 195-210, 2014.

[41] E. Stephenson, N. Nathoo, Y. Mahjoub, J. F. Dunn, and V. W. Yong, "Iron in multiple sclerosis: roles in neurodegeneration and repair," Nature Reviews Neurology, vol. 10, no. 8, pp. 459468, 2014.

[42] T. Kimura, A. Onodera, F. Okumura, T. Nakanishi, and N. Itoh, "Chromium (VI)-induced transformation is enhanced by $\mathrm{Zn}$ deficiency in BALB/c 3T3 cells," Journal of Toxicological Sciences, vol. 40, no. 3, pp. 383-387, 2015.

[43] L. Huang, X. Yu, J. Zhang et al., "Metal element excretion in 24$\mathrm{h}$ urine in patients with wilson disease under treatment of Dpenicillamine," Biological Trace Element Research, vol. 146, no. 2, pp. 154-159, 2012.

[44] S. Q. Xu, X. F. Li, H. Y. Zhu, Y. Liu, F. Fang, and L. Chen, "Clinical efficacy and safety of chelation treatment with typical penicillamine in cross combination with DMPS repeatedly for Wilson's disease," Journal of Huazhong University of Science and Technology: Medical Sciences, vol. 33, pp. 743-747, 2013.

[45] M. Rafati-Rahimzadeh, M. Rafati-Rahimzadeh, S. Kazemi, and A. A. Moghadamnia, "Current approaches of the management of mercury poisoning: need of the hour," DARU: Journal of Pharmaceutical Sciences, vol. 22, article 46, 2014.

[46] W. Kobayashi, S. Yokokura, T. Hariya, and T. Nakazawa, “Two percent ethylenediaminetetraacetic acid chelation treatment for band-shaped keratopathy, without blunt scratching after removal of the corneal epithelium," Clinical Ophthalmology, vol. 9, pp. 217-233, 2015.

[47] C. Exley, U. Ahmed, A. Polwart, and R. N. Bloor, "Elevated urinary aluminium in current and past users of illicit heroin," Addiction Biology, vol. 12, no. 2, pp. 197-199, 2007.

[48] A. Fulgenzi, D. Vietti, and M. E. Ferrero, "Aluminium involvement in neurotoxicity," BioMed Research International, vol. 2014, Article ID 758323, 5 pages, 2014.

[49] E. Panariti and K. Berxholi, "Lead toxicity in humans from contaminated flour in Albania," Veterinary and Human Toxicology, vol. 40, no. 2, pp. 91-92, 1998. 
[50] I. Hininger, R. Waters, M. Osman et al., "Acute prooxidant effects of vitamin C in EDTA chelation therapy and longterm antioxidant benefits of therapy," Free Radical Biology and Medicine, vol. 38, no. 12, pp. 1565-1570, 2005.

[51] A. M. Roussel, I. Hininger-Favier, R. S. Waters, M. Osman, K. Fernholz, and R. A. Anderson, "EDTA Chelation therapy, without added vitamin C, decreases oxidative DNA damage and lipid peroxidation," Alternative Medicine Review, vol. 14, no. 1, pp. 56-61, 2009.

[52] M. Madhusudhanan and S. B. Lall, "Acute lead poisoning in an infant," Oman Medical Journal, vol. 22, pp. 57-59, 2007.

[53] J. Mikler, P. Banovcin, M. Jesenak, J. Hamzikova, and D. Statelova, "Successful treatment of extreme acute lead intoxication," Toxicology and Industrial Health, vol. 25, no. 2, pp.137-140, 2009.

[54] M. Petracca, F. Scafa, R. Boeri, D. Flachi, and S. M. Candura, "Imported occupational lead poisoning: report of four cases," La Medicina del Lavoro, vol. 104, no. 6, pp. 428-433, 2013.

[55] M. E. O'Connor, "CaEDTA vs CaEDTA plus BAL to treat children with elevated blood lead levels," Clinical Pediatrics, vol. 31, no. 7, pp. 386-390, 1992.

[56] H.-W. Gil, E.-J. Kang, K.-H. Lee, J.-O. Yang, E.-Y. Lee, and S.Y. Hong, "Effect of glutathione on the cadmium chelation of EDTA in a patient with cadmium intoxication," Human and Experimental Toxicology, vol. 30, no. 1, pp. 79-83, 2011.

[57] K. Aoyama and T. Nakaki, "Impaired glutathione synthesis in neurodegeneration," International Journal of Molecular Sciences, vol. 14, no. 10, pp. 21021-21044, 2013.

[58] A. Fulgenzi, R. De Giuseppe, F. Bamonti, D. Vietti, and M. E. Ferrero, "Efficacy of chelation therapy to remove aluminium intoxication," Journal of Inorganic Biochemistry, vol. 152, pp. 214-218, 2015.

[59] B. Guldager, K. T. Brixen, S. J. Jorgensen, H. K. Nielsen, L. Mosekilde, and R. Jelnes, "Effects of intravenous EDTA treatment on serum parathyroid hormone (1-84) and biochemical markers of bone turnover," Danish Medical Bulletin, vol. 40, no. 5, pp. 627-630, 1993.

[60] G. A. Lamas, C. Goertz, R. Boineau et al., "Effect of disodium EDTA chelation regimen on cardiovascular events in patients with previous myocardial infarction: the TACT randomized trial," The Journal of the American Medical Association, vol. 309, no. 12, pp. 1241-1250, 2013.

[61] G. A. Lamas, R. Boineau, C. Goertz et al., "EDTA chelation therapy alone and in combination with oral high-dose multivitamins and minerals for coronary disease: the factorial group results of the Trial to Assess Chelation Therapy," American Heart Journal, vol. 168, no. 1, pp. 37-44.e5, 2014.

[62] N. V. Solenkova, J. D. Newman, J. S. Berger, G. Thurston, J. S. Hochman, and G. A. Lamas, "Metal pollutants and cardiovascular disease: mechanisms and consequences of exposure," American Heart Journal, vol. 168, no. 6, pp. 812-822, 2014.

[63] K. A. Moon, E. Guallar, J. G. Umans et al., "Association between exposure to low to moderate arsenic levels and incident cardiovascular disease. A prospective cohort study," Annals of Internal Medicine, vol. 159, no. 10, pp. 649-659, 2013.

[64] M. Tellez-Plaza, E. Guallar, B. V. Howard et al., "Cadmium exposure and incident cardiovascular disease," Epidemiology, vol. 24, no. 3, pp. 421-429, 2013.

[65] P. Ouyang, S. H. Gottlieb, V. L. Culotta, and A. Navas-Acien, "EDTA chelation therapy to reduce cardiovascular events in persons with diabetes," Current Cardiology Reports, vol. 17, no. 11, article 96, 2015.
[66] M. Chin-Chan, J. Navarro-Yepes, and B. Quintanilla-Vega, "Environmental pollutants as risk factors for neurodegenerative disorders: Alzheimer and Parkinson diseases," Frontiers in Cellular Neuroscience, vol. 9, article 124, 2015.

[67] A. Carocci, N. Rovito, M. S. Sinicropi, and G. Genchi, "Mercury toxicity and neurodegenerative effects," Reviews of Environmental Contamination and Toxicology, vol. 229, pp. 1-18, 2014.

[68] A. Fulgenzi, R. De Giuseppe, F. Bamonti, and M. E. Ferrero, "Improvement of oxidative and metabolic parameters by cellfood administration in patients affected by neurodegenerative diseases on chelation treatment," BioMed Research International, vol. 2014, Article ID 281510, 9 pages, 2014.

[69] A. Čabarkapa, S. Borozan, L. Živković et al., "CaNa2EDTA chelation attenuates cell damage in workers exposed to lead-a pilot study," Chemico-Biological Interactions, vol. 242, pp. 171178, 2015.

[70] G. Mosayebi, D. Haghmorad, S. Namaki, A. Ghazavi, P. Ekhtiari, and A. Mirshafiey, "Therapeutic effect of EDTA in experimental model of multiple sclerosis," Immunopharmacology and Immunotoxicology, vol. 32, no. 2, pp. 321-326, 2010.

[71] S.-K. Yang, L. Xiao, P.-A. Song, X.-X. Xu, F.-Y. Liu, and L. Sun, "Is lead chelation therapy effective for chronic kidney disease? A meta-analysis," Nephrology, vol. 19, no. 1, pp. 56-59, 2014.

[72] A. I. Sánchez-Fructuoso, J. Blanco, M. Cano et al., "Experimental lead nephropathy: treatment with calcium disodium ethylenediaminetetraacetate," American Journal of Kidney Diseases, vol. 40, no. 1, pp. 59-67, 2002.

[73] C. Foglieni, A. Fulgenzi, P. Ticozzi et al., "Protective effect of EDTA preadministration on renal ischemia," BMC Nephrology, vol. 7, article 5, 2006.

[74] K.-H. Chen, J.-L. Lin, D.-T. Lin-Tan et al., "Effect of chelation therapy on progressive diabetic nephropathy in patients with type 2 diabetes and high-normal body lead burdens," American Journal of Kidney Diseases, vol. 60, no. 4, pp. 530-538, 2012.

[75] W.-H. Huang, J.-L. Lin, D.-T. Lin-Tan, C.-W. Hsu, K.-H. Chen, and T.-H. Yen, "Environmental lead exposure accelerates progressive diabetic nephropathy in type II diabetic patients," BioMed Research International, vol. 2013, Article ID 742545, 9 pages, 2013.

[76] D.-T. Lin-Tan, J.-L. Lin, T.-H. Yen, K.-H. Chen, and Y.-L. Huang, "Long-term outcome of repeated lead chelation therapy in progressive non-diabetic chronic kidney diseases," Nephrology Dialysis Transplantation, vol. 22, no. 10, pp. 2924-2931, 2007.

[77] J.-L. Lin, D.-T. Lin-Tan, K.-H. Hsu, and C.-C. Yu, "Environmental lead exposure and progression of chronic renal diseases in patients without diabetes," The New England Journal of Medicine, vol. 348, no. 4, pp. 277-286, 2003.

[78] J.-L. Lin, D.-T. Lin-Tan, C.-C. Yu, Y.-J. Li, Y.-Y. Huang, and K.-L. Li, "Environmental exposure to lead and progressive diabetic nephropathy in patients with type II diabetes," Kidney International, vol. 69, no. 11, pp. 2049-2056, 2006.

[79] I. Sabolić, "Common mechanisms in nephropathy induced by toxic metals," Nephron-Physiology, vol. 104, no. 3, pp. 107-114, 2006.

[80] A. S. Lossinsky and R. R. Shivers, "Structural pathways for macromolecular and cellular transport across the blood-brain barrier during inflammatory conditions. Review," Histology and Histopathology, vol. 19, no. 2, pp. 535-564, 2004.

[81] R. Deane, R. D. Bell, A. Sagare, and B. V. Zlokovic, "Clearance of amyloid- $\beta$ peptide across the blood-brain barrier: implication for therapies in Alzheimer's disease," CNS and Neurological Disorders-Drug Targets, vol. 8, no. 1, pp. 16-30, 2009. 
[82] M. C. Ferguson, S. Saul, R. Fragkoudis et al., "Ability of the encephalitic arbovirus semliki forest virus to cross the blood-brain barrier is determined by the charge of the E2 glycoprotein," Journal of Virology, vol. 89, no. 15, pp. 7536-7549, 2015.

[83] B. J. Kim, B. M. Hancock, A. Bermudez et al., "Bacterial induction of Snaill contributes to blood-brain barrier disruption," Journal of Clinical Investigation, vol. 125, no. 6, pp. 2473-2483, 2015.

[84] A. Louveau, I. Smirnov, T. J. Keyes et al., "Structural and functional features of central nervous system lymphatic vessels," Nature, vol. 523, no. 7560, pp. 337-341, 2015.

[85] S. Benedetti, S. Catalani, F. Palma, and F. Canestrari, "The antioxidant protection of CELLFOOD ${ }^{\circledR}$ against oxidative damage in vitro," Food and Chemical Toxicology, vol. 49, no. 9, pp. 2292-2298, 2011.

[86] E. Ferrero, A. Fulgenzi, D. Belloni, C. Foglieni, and M. E. Ferrero, "Cellfood ${ }^{\mathrm{TM}}$ improves respiratory metabolism of endothelial cells and inhibits hypoxia-induced reactive oxygen species (ROS) generation," Journal of Physiology and Pharmacology, vol. 62, no. 3, pp. 287-293, 2011.

[87] S. W. Caito and M. Aschner, "Mitochondrial redox dysfunction and environmental exposures," Antioxidants and Redox Signaling, vol. 23, no. 6, pp. 578-595, 2015.

[88] M. D. Avila, E. Escolar, and G. A. Lamas, "Chelation therapy after the trial to assess chelation therapy: results of a unique trial," Current Opinion in Cardiology, vol. 29, no. 5, pp. 481-488, 2014.

[89] J. G. Peguero, I. Arenas, and G. A. Lamas, "Chelation therapy and cardiovascular disease: connecting scientific silos to benefit cardiac patients," Trends in Cardiovascular Medicine, vol. 24, pp. 232-240, 2014.

[90] G. A. Lamas, "Cardiology Patient Page. Chelation therapy: a new look at an old treatment for heart disease, particularly in diabetics," Circulation, vol. 131, no. 21, pp. e505-e506, 2015. 

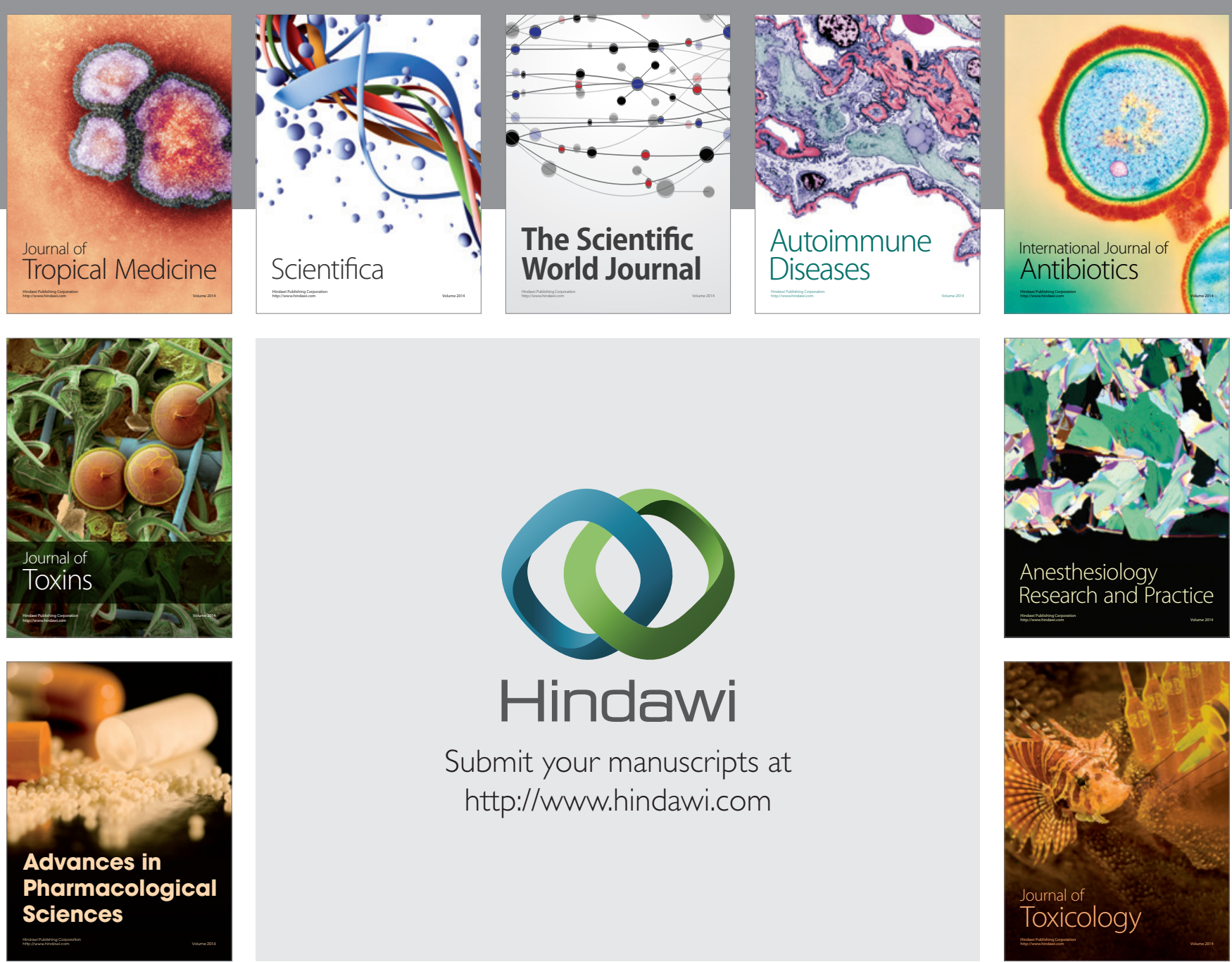

\section{Hindawi}

Submit your manuscripts at

http://www.hindawi.com
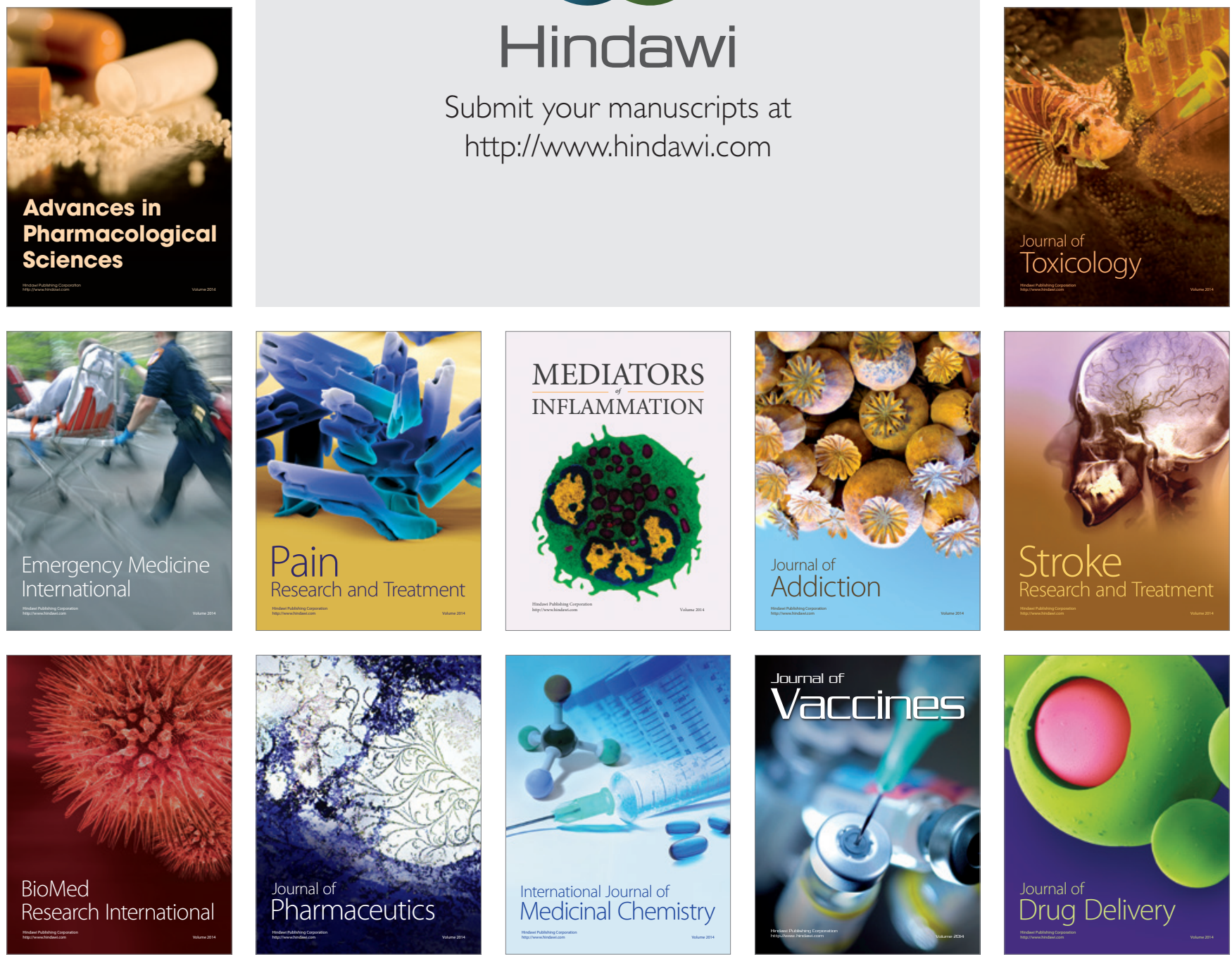